\title{
Methods and models for increasing the level of aviation security of airports
}

\author{
V. A. Temnikov*, E. L. Temnikova \\ https://doi.org/10.31174/SEND-NT2018-157VI17-17 \\ National Aviation University, Kyiv, Ukraine \\ National Technical University of Ukraine «Igor Sikorsky Kyiv Polytechnic Institute», Kyiv, Ukraine \\ *Corresponding author. E-mail: temnikov_v@ukr.net \\ Paper received 27.01.18; Accepted for publication 05.02.18.
}

\begin{abstract}
The level of aviation security of the airport substantially depends on the state of the system for countering acts of unlawful interference with airports (SCAUI), which is a set of technical systems and devices used in the performance of operational procedures for the inspection of passengers, hand luggage, baggage, etc., security. It is noted that the improvement of airport security can be achieved only with the systematic use of organizational and technical measures, as well as measures aimed at reducing the impact of the human factor on the effectiveness of the aviation security service. The article describes the components of information technology (model methods) for proactive management of SCAUI state levels and the functional state of aviation security service employees.
\end{abstract}

Keywords: aviation security, airport, aviation security service, functional state, psycho-physiological resource.

Introduction. Analytic analysis shows that aviation security (AS) in many countries, including Ukraine, is at an unsatisfactory level [1,2], which is manifested, in particular, in the inability to prevent terrorist acts.

In accordance with [3-6], it is currently relevant to ensure the safety of aircraft and AS is the application of a set of measures - technical, organizational and aimed at reducing the impact of the human factor. Note that to ensure security, it is the reduction of the negative impact of the human factor on the emergence and development of emergencies is the most important and, at the same time, difficult task to solve.

An substantial role in the provision of AS is for airport employees of AS services - the correctness and literacy of their actions in protecting passengers, airport employees, aircraft, cargo and information from deliberate acts of intruders committing acts of illegal interference (AUI) determine the effectiveness of the protection of airports from AUI. in turn, the effectiveness of the AS service depends on the quality of the organization of work and the technical equipment of the AS service, and, to a large extent, the functional state of their employees. It is unintentional errors of AS service employees, caused by their being in an inadequate physical, physiological or mental condition, which are one of the main causes of accidents.

From the above, the urgency of solving the problem of developing methods and means of increasing the level of AS airports, aimed primarily at:

- improvement of the AS service to counteract AUI.

- decrease in the influence of the human factor on airport security (identification and elimination of the causes that cause the negative impact of the human factor on safety).

In this article, the main provisions of the information technology developed by the authors (methods and models) are presented, the application of which allows increasing airports AS.

The method of proactive quality management AS airport. The basis of the method is to identify the factors that have a determining influence on AS, and the implementation of actions aimed, first of all, at working with these factors.

The main steps of the method are:

1. Expert evaluation of the quality (level) of the airport AS (the effectiveness of the AS service of airports).
2. Identification of the factors that determine the quality of AS airport.

3. Improving the quality of factors that have a determining effect on the AS airport.

At the heart of the description of the problem area is the graph hierarchical model of the AUI (SCAUI). The nodes (vertices) of the graph are elements of the process of organization and security of the airport.

The model can have a relatively large (up to five or six) levels of hierarchy. The output level is the quality (level) of the airport airspace, and the entry level is the parameters that characterize the functional state of the SAB employees, airport security systems and technical devices used by AS service officers when inspecting passengers, hand luggage, luggage, aircraft, provision of in-site mode and passage mode of airport employees (implementation of in-site and throughput control) and other actions to ensure airport security.

Elements of the intermediate levels of the model are: the quality of preflight inspection of passengers and hand luggage, the quality of passport and ticket control of passengers, the quality of preflight inspection of luggage, the quality of organization and provision of an internal facility, the quality of the organization and providing an admission regime for the airline (the indicated vertices of the graph may be elements of the third level); the quality of preflight control of passengers and luggage, the quality of organization and security of controlled zones and aircraft (the indicated vertices of the graph may be elements of the fourth level of the graph), etc.

The vertices are connected with each other by directed loaded arcs characterizing the effect of the elements of one level of the model on the others. The strength of the influence of bonds (the loading of arcs) is measured by interval values (a particular case of using a fuzzy set of type 2) [7].

The novelty of the developed information technology is the use of perceptual computations [7, 8], based on the use of fuzzy mathematics. The application of the theory of fuzzy sets allows us to overcome the uncertainties in the description of the subject area related to subjective human thinking and to obtain a quantitative assessment of the quality (level) of the airport's airspace and the effectiveness (quality) of the AS service activities. In this case, it is proposed to use fuzzy sets of interval type (type 2) [7], since they give an advantage when using linguistic varia- 
bles. The use of perceptual computing (perceptual computer) becomes expedient due to the fact that experts evaluate the situation (in our case - quality, AS level) linguistically, which is natural for subjective evaluation. After all, as L. Zade wrote, "Man thinks not by numbers, but by fuzzy concepts" [9]. The experts are able to assess the level (quality) in a linguistic form (with the use of linguistic variables), which ultimately simplifies their work.

Analysis of the procedure for organizing and ensuring the security of the airport showed that the quality (level) of its AS depends on the pre-flight control of passengers and baggage and the quality of the organization and ensuring the safety of controlled zones and aircraft. These indicators are elements of the penultimate level of the model.

In turn, the quality of preflight control of passengers and baggage depends on the quality of preflight inspection of passengers and hand baggage, the quality of passport and ticket control of passengers and the quality of preflight control of luggage, and the quality of organization and ensuring the safety of controlled areas and aircrafts - from the quality of organization and provision of in-site mode, the access mode of airport employees and access to controlled areas.

Elements of one of the intermediate levels of the model are security alarm systems, video surveillance, access control systems, technical means used in carrying out appropriate operating procedures and the functional condition of AS service employees performing various types of control of passengers, hand luggage, baggage,

The authors developed a method for identifying factors that exert a decisive influence on the quality (level) of the airport's airspace by solving the problem (in relation to the problem of expert evaluation of the quality of the airport's airspace). The task of isolating from a set of factors that affect AS, a subset of factors sufficient to ensure the given quality of the objective function increase of AS airports) is solved using one of the most significant elements of the theory of fuzzy logic - the construction of fuzzy logic in a poorly formalized system action of the AUI [10].

The calculations carried out by the authors with the use of the model developed by them and the algorithm of unclear output showed that one of the significant factors affecting the airport AS is the functional state of the AS service staff. As one of the ways to improve the quality of management of the functional state of AS service employees, the authors suggest improving the psychophysiological control of the degree of capacity and willingness of the staff of the AS service of the airport to perform the professional duties carried out at the time of the acceptance of the work, carry out periodic and pre-control monitoring, as well as training and professional development of AS service employees using simulators.

Improving the quality of assessment and forecasting the ability AS service employees to perform professional duties. One of the main factors that determine the ability of a person to perform professional duties, along with the person's necessary knowledge, skills and abilities, is his functional state (state of health, stress and emotional stability, etc.).
Increase the effectiveness (quality) of monitoring the functional status of job seekers (during employment) and airport employees (during periodic monitoring, training and in-service training when working on simulators) is proposed by:

1) improving the methodology of testing on the basis of introducing additional elements of psychophysiological control;

2) introduction of proactive management of the functional state of airport staff on the basis of predicting changes in their psycho-physiological state for a long period of time with subsequent verification of the forecast.

It is proposed to introduce a new indicator characterizing a person's ability to perform professional (official) duties - a psycho-physiological resource (PPR), determined on the basis of assessing the state of the cardiovascular system of a person. It is known that the state of the cardiovascular system is an integral characteristic that allows to assess the state of the regulating systems of the human body and its adaptive capabilities.

At present, the most informative noninvasive method of quantitative evaluation of the functional state of a human organism is the determination of the variability of the heart rhythm - the variability of the duration of intervals of sequential cycles of cardiac contractions over definite intervals of time $[11,12]$.

The state of the cardiovascular system can be assessed using the activity regulator (RSAI), which allows differentiating different degrees of stress in the human body's regulatory systems and assessing the adaptive capabilities of the body.

RSAI is calculated in points (from 1 to 10) according to a special algorithm that takes into account statistical indicators, histogram indicators of the distribution of cardiointerval durations, and spectral analysis of cardiointervals.

Based on the analysis of the RSAI values, the following functional states can be diagnosed:

- the state of the optimal (working) stress of regulatory systems;

- the state of moderate stress of regulatory systems, when additional functional reserves are required for adaptation to environmental conditions; such conditions arise in the process of adaptation to work activity, emotional stress or under the influence of unfavorable environmental factors;

- the state of the expressed stress of regulatory systems, which is associated with the active mobilization of protective mechanisms;

- the state of overstrain of regulatory systems, for which the defensive-adaptive mechanisms are inadequate, their inability to provide an adequate response of the organism to the influence of environmental factors.

The functional state of the examined person according to the results of the RSAI calculation can be attributed to one of their classes [12]: the state of the norm (state of satisfactory adaptation) - with RSAI $=1-3$, the functional stress state - with RSAI $=4-5$ and the overstress condition (unsatisfactory state adaptation) - with RSAI $=6-7$. Taking into account the significance of the RSAI, a decision is made on the person's ability to perform job duties. 
RSAI allows you to obtain only discrete estimates of functional states, which is not enough for dynamic control.

Based on the results of periodic monitoring and work on training simulators, the PPR is forecasted for a long period of time with the use of the developed method of predicting a person's ability to perform professional (official) duties. The novelty of the developed method consists in using not only statistical, but also qualitative indicators of the state, as well as their determination by prognostic modeling with the use of time series. Three groups of factors have been identified, under which the values of the time series elements are formed: long-term, cyclical and random.

The task of forecasting is formulated as the task of choosing a rational prediction of a set of alternatives using predictive models with an additive structure, taking into account the professional qualities of the airport personnel, their PPR dependence on climatic, temporary, stressful and other factors affecting the staff's condition. Taking into account these factors, it is most possible to simulate the entire spectrum of forecast models and determine the most probable.

To conduct the prediction of the PPR for a long period of time, tests and results of work on the simulators are used. Persons making decisions on hiring candidates for jobs and making an opinion on the ability of the applicant to perform job duties must use databases containing:

- parameters characterizing the human condition, determined during the tests, consisting in the impact on the applicant of the dosed information load;

- the results of physical, physiological and mental control (medical control) conducted during periodic checks;

- the results of each premenus medical check of the physical, physiological and mental state carried out.

Ways to improve the quality of control over the readiness of airport staff to perform professional duties. The basis for admission or admission of staff to the AS service to professional activities in the health status are the results of medical examinations, one of which is the timely identification and removal of workers with initial forms of the disease and reduced performance due to fatigue associated with inadequate sleep, excessive physical exertion, disturbance of the relaxation regime, or other reasons.

The decision on whether a AS service employee can perform his professional duties can be made on the basis of a comprehensive analysis of a set of several informative signs of a person, by which the status of various human systems can be judged, which will allow to more objectively identify the symptoms of depression, fatigue, stress.

At present, pre-term medical supervision usually includes a survey (in which complaints about health status, rest conditions, diet), evaluation of speech, facial expressions, emotional state (calm, inhibited, excited), examination of appearance, skin condition, oral cavity, pupil response to light, pulse examination, blood pressure measurement and body temperature measurement.

This is clearly not enough to make an informed decision on admission or non-admission to work. Objective results of medical pre-control monitoring can be obtained only on the basis of its improvement by introducing new progressive methods for determining the functional state of AS service employees, identifying their symptoms of depression, fatigue, stress, and automating the processing of results and the decision-making process.

In order to improve the quality of pre-flight monitoring of the functional status of an airport employee, it is suggested, as in the case of recruitment and periodic monitoring, to evaluate its psychophysiological resource. The definition and analysis of the PPR will help the doctor in setting the right diagnosis of the state of health and making a more informed decision about the degree of the person's readiness to perform his professional duties.

Proposed as an indicator of readiness to apply the "stress index", proposed by prof. Bayevsky R.M. [11, 12]. This indicator is advisable to apply not only to the characteristics of the PPR before the shift begins, but also when analyzing changes in the functional state of a person during the shift. The impact of mental or physical stress on a person manifests itself in the form of stabilization of the heart rate, a decrease in the spread of cardiointerval durations, an increase in the number of intervals of the same length.

The stress index of human regulatory systems (SI), like RSAI, is determined by an electrocardiogram by measuring the variability of the heart rhythm. However, in this case, a portable electrocardiograph may be used.

In the norm, SI varies between 80 and 150 conventional units. In people with a healthy cardiovascular system, against a background of stress, increased attention, readiness, this indicator sometimes rises to 200-300, and, the higher this index, the greater the level of stress.

In order to improve the quality of pre-check monitoring by a doctor who is the person making decisions on admitting / not allowing airport employees to work, a knowledge base has been developed in which, based on an improved methodology for assessing the person's readiness to perform professional duties, an appropriate system of rules for the use of information contained in corresponding databases. The application of this knowledge base allows the specialist (doctor) to take into account the dynamics of the change in the functional state of a person from shift to shift, the trend of changes in the PPR at the end of the shift with respect to the PPR at the beginning of the shift (based on the results of pre- and post-shift psycho-physiological control), as well as the results of prediction of the PPR for a long period of time.

Indicators of the functional state, obtained as a result of pre-control, should be included in the database. Based on the results of pre-control monitoring, recommendations should be developed to maintain the state of the person at the level necessary for its production activities and to assess the need for rehabilitative activities.

Conclusions. 1. The graph hierarchical model of the SCAUI system and the provisions of information technology (methods and models) are developed, the application of which allows to increase the airport airspace.

2 . The method of proactive quality management of the airport is developed, the basis of which. is to identify the factors that have a determining effect on the AS, and the implementation of actions aimed, first of all, to work with these factors. 
3. The analysis, carried out using the developed models and methods, has shown that an effective increase of AS airports can be achieved on the basis of:

- improving the effectiveness (quality) of controlling the degree of ability and readiness of AS service airport staff to perform professional duties conducted to reduce the human factor on the AS;

- upgrading the technical equipment of employees of certain AS service units.

4. Reduction of the influence of the human factor on the AS can be achieved on the basis of improving the psychophysiological control during the admission of the employee to work, conducting periodic and pre-control monitoring based on the analysis of the integral indicator - the state of the human cardiovascular system. Evaluate the state of the cardiovascular system based on the results of the calculation of the activity index of the regulatory systems of the human body (RSAI) and the stress index (SI), based on the analysis of variable minute heart rate.

5. To increase the effectiveness of management of the psychophysiological condition of AS service staff, it is proposed to carry out forecasting of changes in their psychophysiological resource using the developed method and the results of work on the simulator.

\section{ЛИТЕРАТУРА}

1. Safety Report // International Civil Aviation Organization, 7. Liu F., Mendel J.M. Encoding words into interval type-2 2017. Published in Montréal, Canada. 28 p.

2. Аналіз стану безпеки польотів // Державна авіаційна служба України, 2016. 25 с.

3. Doc 9859 "Safety Management Manual" // International Civil Aviation Organization, 2013. $251 \mathrm{p}$.

4. Doc 8973/9 "Aviation Security Manual" // International Civil Aviation Organization, 2014. 818 p.

5. Doc 9808 "Human Factors in Civil Aviation Security Operations" // International Civil Aviation Organization, 2002. $120 \mathrm{p}$.

6. Annex 17: Security : Safeguarding International Civil Aviation Against Acts of Unlawful Interference // International Civil Aviation Organization, 2017. 62 p.

fuzzy sets using an Interval Approach // IEEE Trans. on Fuzzy Systems, December 2008. Vol. 16. P. 1503-1521.

8. Zadeh L. A. Fuzzy logic = computing with words // IEEE Trans. on Fuzzy Systems, vol. 4, 1996. P. 103-111.

9. Zadeh L. A. Fuzzy sets // Information and control, 1965.Vol. 8(3), ol. 8(3). P. 338-353.

10. Mamdani, E. H. Application of fuzzy algorithms for the control of a simple dynamic plant // In Proc IEEE, 1974. P.121-159.

11. Баевский Р.М., Кириллов О.И., Клецкин С.3. Математический анализ изменений сердечного ритма при стрессе. М.: Наука, 1984. 220 с.

12. Баевский Р.М., Берсенева А.П. Оценка адаптационных возможностей организма и риск развития заболеваний. М.: Медицина, 1997. 265 с.

\section{REFERENCES}

1. Safety Report // International Civil Aviation Organization, 7. Liu F., Mendel J.M. Encoding words into interval type-2 2017. Published in Montréal, Canada. 28 p.

2. Safety review // State Aviation Administration of Ukraine, 2016. 25 p.

3. Doc 9859 "Safety Management Manual" // International Civil Aviation Organization, 2013. $251 \mathrm{p}$.

4. Doc 8973/9 "Aviation Security Manual" // International Civil Aviation Organization, 2014. 818 p.

5. Doc 9808 "Human Factors in Civil Aviation Security Operations" // International Civil Aviation Organization, 2002. 120 p.

6. Annex 17: Security : Safeguarding International Civil Aviation Against Acts of Unlawful Interference // International Civil Aviation Organization, 2017. 62 p. fuzzy sets using an Interval Approach // IEEE Trans. on Fuzzy Systems, December 2008. Vol. 16. P. 1503-1521.

8. Zadeh L. A. Fuzzy logic = computing with words // IEEE Trans. on Fuzzy Systems, vol. 4, 1996. P. 103-111.

9. Zadeh L. A. Fuzzy sets // Information and control, 1965.Vol. 8(3), ol. 8(3). P. 338-353.

10. Mamdani, E. H. Application of fuzzy algorithms for the control of a simple dynamic plant // In Proc IEEE, 1974. P.121-159.

11. Bayevsky R.M., Kirillov O.I., Kletskin S.Z. Mathematical analysis of heart rate changes under stress. Moscow: Nauka, 1984. $220 \mathrm{p}$.

12. Bayevsky R.M., Berseneva A.P. Assessment of the adaptive capabilities of the body and the risk of developing diseases. Moscow: Medicine, 1997. 265 p.

\section{Методы и модели повышения уровня авиационной безопасности аэропортов}

\section{В. А. Темников, Е. Л. Темникова}

Аннотация. Уровень авиационной безопасности (АБ) аэропортов существенно зависит от состояния системы противодействия актам незаконного вмешательства в их деятельность (СПАНВ), представляющей собой совокупность технических систем и устройств, применяемых при выполнении эксплуатационных процедур по обеспечению досмотра пассажиров, ручной клади, багажа и др., и соответствующих сотрудников службы АБ. При этом отмечается, что повышение безопасности аэропортов может быть достигнуто лишь при системном применении организационных и технических мер, а также мер, направленных на снижение влияния человеческого фактора на эффективность деятельности службы АБ. В статье приведены составляющие информационной технологии (модели методы) процессов проактивного управления уровнями состояния СПАНВ и функционального состояния сотрудников службы АБ.

Ключевые слова: авиационная безопасность, аэропорт, служба авиационной безопасности, функииональное состояние, психофизиологический ресурс. 